Präsident: Ich glaube, die Hauptvortragenden haben uns gezeigt, daß man durchaus in begrenzter Zeit das gestellte Problem sehr prägnant darstellen kann.

Wir fahren mit den Ergänzungsvorträgen fort. Ich habe ein wenig die Hoffnung und die Bitte im Hinblick auf eine ersprießliche Forumsdiskussion, daß sich die nachfolgenden Redner vielleicht doch in der Lage sehen, eine, wenn nicht zwei Minuten von ihrer Redezeit einzusparen.

\title{
113. Erfahrungen mit der Kontinenzerhaltung bei der chirurgischen Behandlung von 900 Rectumearcinomen
}

\author{
R. KÜHLMAYER-Wien/Österreich
}

Experience with the Preservation of Continence in Surgical Treatment of 900 Cases of Rectum Carcinoma

Summary. During the period 1950-1970 903 cases of rectum carcinoma were operated on at the Surgical Policlinic, Vienna, with a rate of operability of $94 \%$. The limit for resection being set at a level of $7 \mathrm{~cm}$ above the sphincter-measured during operation with the rectum completely mobilised-66.1\% of cases were operated on with preservation of continence, $33.9 \%$ by extirpation. The mortality of resections up to the age of 70 was $6.3 \%$, over $7012.8 \%$. The mortality of extirpation up to the age of 70 was $8.1 \%$, age 70 to $8614.9 \% .50 \%$ of the survivors were alive after 5 years, the fate of $18 \%$ is unknown. The patients with resection are continent with few exceptions, as proved by rectal pressure measurements (film).

Zusammenfassung. An der chir. Poliklinik in Wien sind zwischen 1950 und 1970903 Rectumcarcinome operiert worden, was einer Operabilitätsquote von 94\% entspricht. Bei der Festlegung der Grenze zwischen Exstirpation und Resektion in der Höhe von $7 \mathrm{~cm}$ über dem Sphincter - gemessen am intraoperativ komplett mobilisierten Rectum - wurden $66,1 \%$ der Fälle kontinenzerhaltend operiert, $33,9 \%$ mußten exstirpiert werden.

Die Mortalität der Resektionen betrug bis zum 70. Lebensjahr 6,3\%, jenseits des 70. Lebensjahres 12,8\%, die Mortalität der Exstirpationen bis zum 70 . Lebensjahr $8,1 \%$, zwischen 70 . und 86. Lebensjahr 14,9\%.

$\tilde{n} 0 \%$ der Ǔberlebenden erreichten eine Fünfjahresheilung, wobei das Schicksal von $18 \%$ noch unbekannt ist.

Die resezierten Patienten sind mit wenigen Ausnahmen kontinent, was an Hand von Druckmessungen im Rectum nachgewiesen werden konnte (Film).

Präsident: Wir beglückwünschen Sie herzlich zu diesem Erfolg. Wir haben diesen Weg früher auch selbst gewählt, haben ihn dann aber doch wieder verlassen, weil die Gefahr der mangelhaften Radikalität zu groß war. Vielleicht können wir uns später in der Diskussion nochmals darüber unterhalten. 